Pak. j. sci. ind. res. Ser. B: biol. sci. 2017 60(2) 87-91

\title{
The Effect of Beta Cyclodextrin on the Removal of Cholesterol from Buffalo Milk
}

\author{
Muhammad Nadeem, Zunnurain* and Hafiza Anam Baig \\ Department of Dairy Technology, University of Veterinary and Animal Sciences, Lahore, Pakistan
}

(received April 16, 2015; revised October 6, 2015; accepted December 1, 2016)

\begin{abstract}
This study was conducted to find out the efficiency of beta cyclodextrin $(\beta C D)$ for the removal of cholesterol from buffalo milk. Standardised (3.5\% fat) and homogenised buffalo milk was treated with $\beta C D$ at three different concentrations i.e., $0.5,1$ and 1.5\% $\left(\mathrm{T}_{1}, \mathrm{~T}_{2}\right.$ and $\left.\mathrm{T}_{3}\right)$ and compared with a control without $\beta C D$ treatment. Treatment of milk with $\beta C D$ at all concentrations did not show any negative impact on $\mathrm{pH}$ and acidity of milk. $90 \%$ cholesterol was removed when buffalo milk was treated with $1.5 \% \beta C D$. Treatment of milk with $\beta C D$ did not reveal significant effect on fatty acid and triglyceride composition of milk as well as physicochemical and sensory characteristics $(\mathrm{P}>0.05)$. These results depicted that $\beta C D$ can be used efficiently for the removal of cholesterol from buffalo milk.
\end{abstract}

Keywords: beta cyclodextrin, cholesterol, fatty acid profile, triglyceride profile, buffalo milk

\section{Introduction}

Dietary cholesterol has been implicated in the development of cardiovascular diseases (Hansel et al., 2007). Milk contains about $0.25-0.35 \mathrm{~g} / 100 \mathrm{~g}$ cholesterol (McSweeney and Fox, 2003). Milk with lower concentration of dietary cholesterol is beneficial for hypercholesterolemic and hypertensive individuals. Good quality yoghurt, ice cream and cheese can be made from low cholesterol milk (Nadeem et al., 2015; Lee et al., 2007). South Asia has five groups of buffalo breeds (Murrah, Gujrati, Uttar Pradesh, Central Indian and South Indian). Nili- Ravi is regarded as the best performing animal of this group, in terms of milk yield per lactation. Many techniques have been developed for the removal of cholesterol from milk and milk products. The application of beta cyclodextrin $(\beta C D)$ in milk and milk products is superior to other techniques of cholesterol removal in terms of efficiency and safety of treated stuffs (Lee et al., 2007). The insolubility of $\beta C D$ in milk serum offers a unique benefit of cholesterol removal with negligible amount of residues in the treated stuffs. Scientific studies have evidenced that residues of $\beta C D$ do not have harmful effects in human body and intestinal micro flora can fully decompose residues of $\beta C D$ (Loftsson and Brewster, 1996). Removal of cholesterol from cow milk and milk products has been studied in detail by Alonso et al. (2009) and Kwak et al. (2002). Several studies have revealed that concentration of beneficial unsaturated fatty acids in milk can be enhanced

*Author for correspondence;

E-mail: zunnurainmudassir@hotmail.com by manipulating the ration of dairy animals. Studies of Brzoska and Sala (2001) have suggested that feeding strategies do not have any significant influence on the concentration of cholesterol in milk. Chemical composition of buffalo is significantly different from cow milk in terms of major and minor constituents (Fox and Mc Sweeney, 1998).

The removal of cholesterol from buffalo milk by $\beta C D$ has not been studied so far. Therefore, it is important to study the suitability of $\beta C D$ in the removal of cholesterol from buffalo milk, which is the second largest source of milk on the globe. This study aimed on the removal of cholesterol from buffalo milk by $\beta C D$ and studies the effect of $\beta C D$ on chemical and sensory characteristics of treated milk.

\section{Materials and Methods}

Raw materials. Buffalo milk was obtained from Livestock Production Research Institute, Bahadar Nagar, Okara, Pakistan. Food grade $\beta C D$ was purchased from Beta Parma Shanghai, China. The reagents used in this study were GC-grade and purchased from Sigma Aldrich Chemical Co. (St. Louis, MO, USA).

Method. Standardised (3.5\% fat) and homogenised milk (200-bar) was treated with $\beta C D$ at three different concentrations i.e., $0.5,1$ and $1.5 \% \mathrm{w} / \mathrm{w}\left(\mathrm{T}_{1}, \mathrm{~T}_{2}\right.$ and $\left.\mathrm{T}_{3}\right)$ and compared with a control without $\beta \mathrm{CD}$ treatment. Milk was heated to $65{ }^{\circ} \mathrm{C}$, standardised at $3.5 \%$ fat, homogenised in a sanitised two stage homogenizer (APV) at 200 and 50 bar pressure in the first and second 
stage, respectively, cooled down to $10^{\circ} \mathrm{C}$, treated with $\beta C D$ at $0.5,1$ and $1.5 \%$ concentrations. Milk was stirred at $800 \mathrm{rpm}$ in a blender (Misung Company, Korea) for twenty minutes then centrifuged at $72 \times \mathrm{g}$ for ten minutes (HMR 220IV, Hanil Industrial Company, Korea). $\beta C D$ treated milk was pasteurised at $65^{\circ} \mathrm{C}$ for $30 \mathrm{~min}$, immediately cooled down, filled into sanitized PET bottles $(250 \mathrm{~mL})$ and stored at $4{ }^{\circ} \mathrm{C}$ for further analysis.

Analysis. Fat from milk was separated by the standard method (AOAC, 1997) and stored at $60{ }^{\circ} \mathrm{C}$ in the biomedical freezer till further analysis (Sanyo). Effect of three various concentrations of $\beta C D$ on milk composition was determined by using Lactoscope Julie, Z-7 Slovakia. Cholesterol was determined using spectrophotometric method of Rudel and Morris (1973). Percentage of cholesterol was measured by dividing the residual concentration with total concentration, followed by multiplication with 100. $200 \mu \mathrm{L}$ of the milk fat sample (dried) was taken in a glass test tube of $15 \mathrm{~mL}$ capacity, dissolved in $3 \mathrm{~mL}$ iso octane and $2 \mathrm{~mL} 0.5 \mathrm{~N}$ sodium methoxide was added in it. Test tube was capped and vortex for $3 \mathrm{~min}$, given the rest of $5 \mathrm{~min}$ to separate the layers. Supernatant was injected into GC through GC syringe (Paquot, 1979). Triglycerides measurement was performed on Agilent GC 6890 equipped with FID and WCOT fused silica capillary column which was $25 \mathrm{~m} \times$ $0.25 \mathrm{~mm}$, coated with OV-17TRI (J.W. Scientific, Folsom, Canada) (Alonso, 1993). Milk fat was characterised for iodine value, refractive index, unsaponifiable matter, free fatty acids, peroxide value and anisidine value according to the standards methods (AOCS, 1990). Colour of milk fat was measured on Lovibond Tintometer (Tintometer Corporation Salisbury, England). Sensory evaluation of low cholesterol milk was performed by a trained panel, comprising of 10 judges. Judges were asked to rate the product according to 9 point scale (1 the worst; 9 the best) as suggested by Larmond (1987).

Statistical analysis. Experiment was organised in a completely randomised design, each treatment was replicated three times and expressed as Mean $\pm \mathrm{SD}$, analysed by one way analysis of variance technique, Duncan Multiple Range Test was applied to investigate the significant difference $(\mathrm{P} \leq 0.05)$ among the treatments (Steel et al., 1997).

\section{Results and Discussion}

Removal of cholesterol from milk. About $90 \%$ cholesterol was removed when milk was treated with $1.5 \% \beta C D$ (Table 1). The considerable removal of cholesterol from milk by $\beta \mathrm{CD}$ can be attributed to the chemical composition of $\beta C D$ molecule, which is comprised of seven glucose units linked in the form of a bottom less bucket; the size of the cavity is exactly similar to the size of cholesterol molecule. Studies of Alonso et al. (2009) reported that $95 \%$ cholesterol was removed, when cow milk was treated with $0.3 \% \beta C D$ at $4{ }^{\circ} \mathrm{C}$ for $20 \mathrm{~min}$ (Alonso et al., 2009). Connors (1997) also reported that chemical structure of $\beta C D$ can help to remove most of the cholesterol from milk and milk products. Entrapment of cholesterol in the $\beta C D$ ring is the combined effect of Van der Waal forces, hydrogen bonding and lipophilic characteristics of the cavity (Martin, 1993). Studies of Oh et al. (1998) depicted milk treatment with saponin and digitonin at various concentrations and reported that removal of cholesterol from milk was not dependent upon the concentration of cholesterol removing agent. Extent of cholesterol removal from milk was dependent upon the dose of $\beta C D$ (Lee et al., 1999).

Table 1. Effect of $\beta C D$ on the removal of cholesterol $(\mathrm{mg} / 100 \mathrm{~g})$

\begin{tabular}{llll}
\hline \hline Treatments & $\begin{array}{l}\text { Before } \beta C D \\
\text { treatment }\end{array}$ & $\begin{array}{l}\text { After } \beta C D \\
\text { treatment }\end{array}$ & \% Removal \\
\hline Control & $0.28 \pm 0.02^{\mathrm{a}}$ & ---- & ---- \\
$\mathrm{T}_{1}$ & $0.28 \pm 0.02^{\mathrm{a}}$ & $0.21 \pm 0.01^{\mathrm{a}}$ & 25.0 \\
$\mathrm{~T}_{2}$ & $0.28 \pm 0.02^{\mathrm{a}}$ & $0.13 \pm 0.02^{\mathrm{b}}$ & 54.5 \\
$\mathrm{~T}_{3}$ & $0.28 \pm 0.02^{\mathrm{a}}$ & $0.03 \pm 0.01^{\mathrm{c}}$ & 89.3 \\
\hline \hline
\end{tabular}

Within a column means denoted by a different letter are statistically different $(\mathrm{P}<0.05)$.

Effect of $\beta C D$ on fatty acid and triglyceride composition. Treatment of milk with $\beta C D$ at the mentioned concentrations did not show any significant effect $(\mathrm{P}>0.05)$ on fatty acid and triglyceride profile of the milk (Table 2). Milk fat is unique among all the dietary fats for having appreciable amount of short chain fatty acids, which are responsible for typical flavour of milk and milk products. Removal of cholesterol from milk by $\beta C D$ does not have any effect on the concentration of short-chain fatty acids. Sensory characteristics of $\beta C D$ treated bulk pasteurized milk were not different from untreated milk (Alonso et al., 2009). Sensory characteristics of ice cream formulated from $\beta C D$ treated milk was not different from control (Nadeem et al., 2015; Bazmi and Relkin, 2009; Ha et al., 2009). The non-variation in the sensory characteristics of ice creams 
could be correlated to the non-significant effect of $\beta C D$ on fatty acid and triglyceride profile of treated milk (Table 3). The cholesterol content of some Pakistani buffalo breeds ranged from 8.89-10.24 mg/dl (Talpur et al., 2007). Triglyceride composition of milk fat treated with $0.6 \% \beta C D$ was not different from untreated milk (Alonso et al., 2009). Other strategies of cholesterol

Table 2. Effect of $\beta C D$ on fatty acid profile of buffalo milk

\begin{tabular}{lllll}
\hline \hline \multirow{2}{*}{$\begin{array}{l}\text { Fatty } \\
\text { acid }\end{array}$} & \multirow{2}{*}{ Control } & \multicolumn{3}{c}{ Treatments } \\
\cline { 3 - 5 } & & $\mathrm{T}_{1}$ & $\mathrm{~T}_{2}$ & $\mathrm{~T}_{3}$ \\
\hline $\mathrm{C} 4: 0$ & $4.17 \pm 0.03$ & $4.15 \pm 0.08$ & $4.14 \pm 0.03$ & $4.12 \pm 0.06$ \\
$\mathrm{C} 6: 0$ & $2.41 \pm 0.05$ & $2.39 \pm 0.10$ & $2.38 \pm 0.02$ & $2.35 \pm 0.02$ \\
$\mathrm{C} 8: 0$ & $2.15 \pm 0.07$ & $2.14 \pm 0.05$ & $2.12 \pm 0.08$ & $2.11 \pm 0.05$ \\
$\mathrm{C} 10: 0$ & $1.83 \pm 0.13$ & $1.80 \pm 0.07$ & $1.79 \pm 0.01$ & $1.78 \pm 0.08$ \\
$\mathrm{C} 12: 0$ & $2.65 \pm 0.02$ & $2.62 \pm 0.04$ & $2.60 \pm 0.04$ & $2.58 \pm 0.07$ \\
$\mathrm{C} 14: 0$ & $11.75 \pm 0.25$ & $11.71 \pm 0.29$ & $11.68 \pm 0.12$ & $11.58 \pm 0.18$ \\
$\mathrm{C} 16: 0$ & $32.27 \pm 0.36$ & $32.16 \pm 0.45$ & $32.11 \pm 0.29$ & $32.09 \pm 0.14$ \\
$\mathrm{C} 18: 0$ & $11.18 \pm 0.19$ & $11.12 \pm 0.11$ & $11.06 \pm 0.15$ & $11.05 \pm 0.19$ \\
$\mathrm{C} 18: 1$ & $24.06 \pm 0.43$ & $24.02 \pm 0.16$ & $24.01 \pm 0.36$ & $23.97 \pm 0.11$ \\
$\mathrm{C} 18: 2$ & $2.34 \pm 0.01$ & $2.33 \pm 0.02$ & $2.31 \pm 0.02$ & $2.29 \pm 0.01$ \\
\hline \hline
\end{tabular}

All means values of control and experimental samples for fatty acid composition mentioned in Table 1 are non-significant $(\mathrm{P}>0.05) ; \mathrm{T}_{1}: 0.5 \% \beta C D ; \mathrm{T}_{2}: 1 \% \beta C D ; \mathrm{T}_{3}: 1.5 \% \beta C D$.

Table 3. Effect of $\beta C D$ on triglyceride profile of buffalo milk

\begin{tabular}{lllll}
\hline \hline \multirow{2}{*}{$\begin{array}{l}\text { Trigly- } \\
\text { ceride }\end{array}$} & Control & \multicolumn{3}{c}{ Treatments } \\
\cline { 2 - 5 } C26 & $0.45 \pm 0.04$ & $0.47 \pm 0.01$ & $0.48 \pm 0.01$ & $0.51 \pm 0.02$ \\
C28 & $1.38 \pm 0.02$ & $1.35 \pm 0.12$ & $1.33 \pm 0.01$ & $1.31 \pm 0.01$ \\
C30 & $2.25 \pm 0.11$ & $2.19 \pm 0.08$ & $2.14 \pm 0.05$ & $2.11 \pm 0.08$ \\
C32 & $4.19 \pm 0.09$ & $4.15 \pm 0.17$ & $4.08 \pm 0.014$ & $4.01 \pm 0.12$ \\
C34 & $6.41 \pm 0.13$ & $6.39 \pm 0.22$ & $6.38 \pm 0.16$ & $6.35 \pm 0.04$ \\
C36 & $11.42 \pm 0.22$ & $11.48 \pm 0.05$ & $11.58 \pm 0.06$ & $11.63 \pm 0.03$ \\
C38 & $14.02 \pm 0.24$ & $14.09 \pm 0.15$ & $14.15 \pm 0.11$ & $14.17 \pm 0.07$ \\
C40 & $11.67 \pm 0.06$ & $11.72 \pm 0.04$ & $11.75 \pm 0.13$ & $11.79 \pm 0.12$ \\
C42 & $6.82 \pm 0.14$ & $6.85 \pm 0.07$ & $6.87 \pm 0.08$ & $6.91 \pm 0.19$ \\
C44 & $5.48 \pm 0.07$ & $5.51 \pm 0.06$ & $5.54 \pm 0.04$ & $5.56 \pm 0.09$ \\
C46 & $6.42 \pm 0.02$ & $5.35 \pm 0.04$ & $6.31 \pm 0.09$ & $6.29 \pm 0.08$ \\
C48 & $7.38 \pm 0.01$ & $7.28 \pm 0.09$ & $7.22 \pm 0.15$ & $7.16 \pm 0.09$ \\
C50 & $9.65 \pm 0.10$ & $9.62 \pm 0.08$ & $9.61 \pm 0.19$ & $9.58 \pm 0.05$ \\
C52 & $8.83 \pm 0.03$ & $8.81 \pm 0.14$ & $8.80 \pm 0.22$ & $8.79 \pm 0.02$ \\
C54 & $3.44 \pm 0.08$ & $3.45 \pm 0.02$ & $3.47 \pm 0.07$ & $3.48 \pm 0.01$ \\
\hline \hline
\end{tabular}

All means values of control and experimental sample for fatty acid and triglyceride composition mentioned in Table 2 are non-significant $(\mathrm{P}>0.05)$. removal has a pronounced effect on triglyceride composition, removal of cholesterol from milk through supercritical fluid extraction significantly affected the triglyceride composition (Chen et al., 2003; GonzalezHierro et al., 1995; Bhaskar et al., 1993).

Effect of $\beta C D$ on milk composition. The results regarding chemical composition of milk treated with various treatments of $\beta C D$ are given in Table 4 . The compositional attributes, $\mathrm{pH}$ and acidity of the treatments were not affected by $\beta C D$ treatment. The non-significant effect on $\mathrm{pH}$ and acidity may be attributed to the neutral nature of $\beta C D$. The non-variation in fat, protein lactose and ash content of treated milk and control could be due to the selective absorption, specific size of the internal cavity of $\beta C D$. Treatment of milk with $\beta C D$ did not have a remarkable effect on the removal of major and minor nutrients of milk, although some water soluble vitamins, short-chain fatty acids, fat, protein and lactose were adsorbed on $\beta C D$ (Ha et al., 2009). Treatment of milk with cross-linked $\beta C D$ did not have a significant effect on the removal of oleic acid, CLA and phospholipids in $\beta C D$ treated milk (Alonso et al., 2009). Lee et al. (2007) did not observe significant difference in chemical composition of $\beta C D$ treated and untreated milk.

Physicochemical properties of fat. The effect of $\beta C D$ on the chemical characteristics of milk fat has been stated in Table 5, that shows that melting point, iodine value and refractive index of all the treatments were non-significantly affected by different concentrations of $\beta C D$. Melting point of the fats depends upon fatty

Table 4. Effect of various concentrations of $\beta C D$ on composition of buffalo milk

\begin{tabular}{lllll}
\hline \hline \multirow{2}{*}{ Parameter } & \multirow{2}{*}{ Control } & \multicolumn{3}{c}{ Treatments } \\
\cline { 3 - 5 } & & $\mathrm{T}_{1}$ & $\mathrm{~T}_{2}$ & $\mathrm{~T}_{3}$ \\
\hline Fat\% & $3.51 \pm 0.08$ & $3.49 \pm 0.04$ & $3.48 \pm 0.02$ & $3.45 \pm 0.15$ \\
Protein\% & $3.22 \pm 0.11$ & $3.22 \pm 0.05$ & $3.21 \pm 0.11$ & $3.21 \pm 0.04$ \\
Lactose\% & $4.78 \pm 0.05$ & $4.78 \pm 0.07$ & $4.76 \pm 0.21$ & $4.79 \pm 0.10$ \\
Ash\% & $0.81 \pm 0.03$ & $0.82 \pm 0.04$ & $0.82 \pm 0.01$ & $0.81 \pm 0.01$ \\
SNF\% & $8.92 \pm 0.22$ & $8.95 \pm 0.11$ & $8.99 \pm 0.17$ & $9.04 \pm 0.15$ \\
TS\% & $12.58 \pm 0.07$ & $12.62 \pm 0.06$ & $12.72 \pm 0.13$ & $12.80 \pm 0.0$ \\
pH & $6.75 \pm 0.08$ & $6.73 \pm 0.05$ & $6.69 \pm 0.01$ & $6.70 \pm 0.03$ \\
Acidity\% & $0.15 \pm 0.01$ & $0.16 \pm 0.02$ & $0.16 \pm 0.03$ & $0.17 \pm 0.01$ \\
\hline \hline
\end{tabular}

All the parameters of milk composition mentioned in Table 4 are non-significantly $(\mathrm{P}>0.05)$ different from each other; $\mathrm{SNF}=$ solids not fat; $\mathrm{TS}=$ total solids. 
Table 5. Effect of $\beta C D$ on physicochemical characteristics of buffalo milk fat

\begin{tabular}{|c|c|c|c|c|c|c|c|c|}
\hline Treatment & MP & IV & FFA & SV & USM & AV & PV & RI \\
\hline Control & $34.8 \pm 0.10$ & $39.15 \pm 0.24$ & $0.08 \pm 0.01$ & $118.49 \pm 0.49$ & $0.68 \pm 0.01 \mathrm{a}$ & $6.16 \pm 0.09$ & $0.25 \pm 0.03$ & $1.452 \pm 0.01 \mathrm{~d}$ \\
\hline $\mathrm{T}_{1}$ & $34.6 \pm 0.20$ & $39.48 \pm 0.34$ & $0.08 \pm 0.02$ & $117.62 \pm 0.64$ & $0.62 \pm 0.03 \mathrm{a}$ & $6.05 \pm 0.12$ & $0.22 \pm 0.01$ & $1.455 \pm 0.01 \mathrm{c}$ \\
\hline $\mathrm{T}_{2}$ & $34.5 \pm 0.1$ & $39.66 \pm 0.22$ & $0.09 \pm 0.02$ & $117.78 \pm 0.85$ & $0.52 \pm 0.01 \mathrm{~b}$ & $5.91 \pm 0.05$ & $0.21 \pm 0.02$ & $1.458 \pm 0.02 b$ \\
\hline $\mathrm{T}_{3}$ & $34.4 \pm 0.10$ & $39.88 \pm 0.19$ & $0.08 \pm 0.01$ & $117.92 \pm 0.55$ & $0.41 \pm 0.01 \mathrm{c}$ & $5.72 \pm 0.09$ & $0.21 \pm 0.01$ & $1.459 \pm 0.01 \mathrm{a}$ \\
\hline
\end{tabular}

The mean value of all the parameters given in Table 3 are statistically non-significant $(\mathrm{P}>0.05)$; MP $=$ melting point $\left({ }^{\circ} \mathrm{C}\right)$; $\mathrm{IV}=$ iodine value (wijs); FFA = free fatty acids $\% ; \mathrm{SV}=$ saponification value; $\mathrm{USM}=$ unsaponifiable matter $\%$; $\mathrm{AV}=$ anisidine value; $\mathrm{PV}=$ peroxide value $\left(\mathrm{meqO}_{2} / \mathrm{kg}\right) ; \mathrm{RI}=$ refractive index $@ 40^{\circ} \mathrm{C}$.

acid composition and solid fat content (Kaylegian and Linsday, 1995). Cholesterol belongs to the unsaponifiable fraction of the lipids of animal origin and possesses high melting point $149.5^{\circ} \mathrm{C}$. Iodine value and refractive index of all the treatment was not different from the control $(\mathrm{P}>0.05)$. Free fatty acids are related to the keeping quality of the fats, higher values are associated with lower keeping quality (Fereidoon, 2005). Anisidine value determines the secondary and tertiary stages of autoxidation (Erickson, 1995). Peroxide value measures the primary stages of oxidative breakdown caused by the free radical mechanism. Treatment of buffalo milk with $\beta C D$ did not reveal any problem of fat oxidation.

Sensory evaluation. Treatment of buffalo milk with $\beta C D$ did not have any negative effect on sensory characteristics of low cholesterol milk (Table 6). A panel of ten trained judges was unable to distinguish low cholesterol milk from normal milk for colour, flavour and aroma. Sensory characteristics of low cholesterol cheddar cheese were not different from standard cheese (Kwak et al., 2002; 1999). Sensory characteristics of dairy products derived from low cholesterol milk was similar to the standard dairy products (Alonso et al., 2009), butter (Kim et al., 2006) and cream (Han et al., 2007; Ortega et al., 2006).

Table 6. Effect of various concentrations of $\beta C D$ on sensory characteristics of buffalo milk

\begin{tabular}{lllll}
\hline \hline Treatment & Colour & Taste & Smell & $\begin{array}{l}\text { Overall } \\
\text { acceptability }\end{array}$ \\
\hline Control & $8.5 \pm 0.21$ & $8.4 \pm 0.05$ & $8.2 \pm 0.05$ & $8.1 \pm 0.09$ \\
$\mathrm{~T}_{1}$ & $8.3 \pm 0.06$ & $8.2 \pm 0.15$ & $8.1 \pm 0.23$ & $8.1 \pm 0.08$ \\
$\mathrm{~T}_{2}$ & $8.2 \pm 0.05$ & $8.0 \pm 0.04$ & $8.1 \pm 0.18$ & $8.0 \pm 0.11$ \\
$\mathrm{~T}_{3}$ & $8.2 \pm 0.10$ & $8.1 \pm 0.08$ & $7.9 \pm 0.02$ & $7.9 \pm 0.12$ \\
\hline
\end{tabular}

All the parameters of sensory evaluation mentioned in Table 5 are no significantly $(\mathrm{P}>0.05)$ different from each other.

\section{Conclusion}

Ninty percent cholesterol was removed when milk was treated with $1.5 \% \beta \mathrm{CD}$. Treatment of buffalo milk with various concentrations of $\beta C D(0.5-1.5 \%)$ did not have any significant effect on fatty acid composition, triglyceride profile, milk composition and physicochemical characteristics of milk fat. Sensory characteristics of low cholesterol milk were almost similar to the control. The overall acceptability score of $\mathrm{T}_{3}$ was 7.9 out 9 (total score) which was more than $87 \%$ of the total score. Cholesterol from buffalo milk can be efficiently removed by $\beta C D$.

\section{Acknowledgement}

Financial assistance for this study was provided by Pakistan Agricultural Research Council under Agricultural Linkages Programme.

\section{References}

Alonso, L., Guesta, P., Fontecha, J., Juarez, M., Gilliland, S.E. 2009. Use of $\beta$-cyclodextrin to decrease the level of cholesterol in milk fat. Journal of Dairy Science, 92: 863-869.

Alonso, L. 1993. Capillary gas chromatography of some triglycerides in cheese using programmed temperature injection. Chromatographia, 35: 649-652.

AOAC, 1997. Official Methods of Analysis, $16^{\text {th }}$ edition, Association of Official Analytical Chemists, AOAC International, Gaithersburg, MD, USA.

AOCS, 1989. Guidelines for collaborative study procedure to validate characteristics of a method of analysis. Journal of AOAC, 72: 694-704.

Bazmi, A., Relkin, P. 2009. Effects of processing conditions on structural and functional parameters of whipped dairy emulsions containing various fatty acid compositions. Journal of Dairy Science, 92: 3566-3574.

Bhaskar, A.R., Rizvi, S.S.H., Sherbon, J.W. 1993. Anhydrous milk fat fractionation with continuous 
countercurrent supercritical carbon dioxide. Journal of Food Science, 56: 748-752.

Brzoska, F., Sala, K. 2001. Milk cholesterol levels in relation to calcium soap and copper content in diets for dairy cows. Journal of Animal and Feed Science, 10: $71-76$.

Chen, J., Lindmark-Mansson, H., Gorton, L., Akesson, B. 2003. Antioxidant capacity of bovine milk as assayed by spectrophotometric and amperometric methods. International Dairy Journal, 13: 927-935.

Connors, K.A. 1997. Population characteristics of cyclodextrin complex stabilities in aqueous solution. Journal of Pharma Science, 84: 843-848.

Erickson, D.R. 1995. Practical Hand Book of Soybean Processing and Utilization, AOCS Press.

Fereidoon, S. 2005. Bailley's Industrial Edible Oil a Fat Products. $6^{\text {th }}$ edition John Wiley and Sons, Pub. Co., New York, USA.

Fox, P.F., Mc Sweeney, P.L.H. 1998. Dairy Chemistry and Biochemistry. pp. 239-264, $1^{\text {st }}$ edition, Blackie Academic and Professional, New York, USA.

Gonzalez-Hierro, M.T., Ruiz-Sala, P., Alonso, L., Santamaria, G. 1995. Extraction of ewe's milk cream with supercritical carbon dioxide. Zeitschrift für Lebensmittel-Untersuchung und-Forschung, 200: 297-300.

Ha, H.J., Ahn, J., Min, S.G., Kwak, H.S. 2009. Properties of cholesterol-reduced ice cream made with crosslinked b-cyclodextrin. International Journal of Dairy Technology, 62: 452-457.

Ha, H.J., Lee, J.E., Chang, J.H., Kwak, H.S. 2009. Entrapment of nutrients during cholesterol removal from cream by crosslinked $\beta$-cyclodextrin. International Journal of Dairy Technology, 63: 119-126.

Han, E.M., Kim, S.H., Ahn, J., Kwak, H.S. 2007. Optimizing cholesterol removal from cream using $\beta$-cyclodextrin cross-linked with adipic acid. International Journal of Dairy Technology, 60: 3136.

Kaylegian, K.E. 1995. Functional characteristics and nontraditional applications of milk lipid components in food and nonfood systems. Journal of Dairy Science, 78: 2524-2540.

Kim, J.J., Jung, T.H., Ahn, J., Kwak, H.S. 2006. Properties of cholesterol-reduced butter made with $\beta$-cyclodextrin and added evening primrose oil and phytosterols. Journal of Dairy Science, 89: 45034510 .

Kwak, H.S., Ahn, J. 1999. Optimization cholesterol removal in cream using $\beta$-cyclodextrin and response surface methodology. Journal of Food Science, 64:
629-632.

Kwak, H.S., Jung, C.S., Shim, S.Y., Ahn, J. 2002. Removal of cholesterol from cheddar cheese by $\beta$-cyclodextrin. Journal of Agriculture and Food Chemistry, 50: 7293-7298.

Larmond, E. 1987. Laboratory Methods for Sensory Evaluation of Foods. pp. 153-156, Reasearch Branch, Department of Agriculture, Ottawa Publications, Canada.

Lee, D.K., Ahn, J., Kwak, H.S. 1999. Cholesterol removal from homogenized milk with $\beta$-cyclodextrin. Journal of Dairy Science, 82: 2327-2330.

Lee, S.J., Hwang, J.H., Lee, S., Ahn, J., Kwak, H.S. 2007. Property changes and cholesterol-lowering effects in evening primrose oil-enriched and cholesterol-reduced yogurt. International Journal of Dairy Technology, 60: 22-30.

Loftsson, T., Brewster, M.E. 1996. Journal of Pharmaceutical Sciences, 85: 1017-1025.

Martin, A. 1993. Physical Pharmacy, pp. 52-59, $4^{\text {th }}$ edition, Lea \& Febiger, Philadelphia, USA.

McSweeney, P.L.H., Fox, P.F. 2003. Advanced Dairy Chemistry, Proteins. vol. 1, $3^{\text {rd }}$ edition, Kluwer Academic Plenum Publication, NY, USA,

Nadeem, M., Rahman Ullah, Imran, M., Arif, A.M. 2015. Effects on physicochemical characteristics of yoghurt and ice cream with fatty acid modification and cholesterol removal. Pakistan Journal of Scientific and Industrial Research, 58: 40-46.

Oh, H.L., Chang, E.J., Kwak, H.S. 1998. Conditions of the removal of cholesterol from milk treatment with saponin. Korean Journal of Dairy Science, 20: 253-260.

Ortega, R.M., Palencia, A., Lopez-Sobaler, A.M. 2006. Improvement of colesterol levels and reduction of cardiovascular risk via consumption of phytosterols. British Journal of Nutrition, 61: 65-67.

Paquot, C. 1979. IUPAC Standard Methods for the Analysis of Oils, Fats and Derivatives, 170 pp., $6^{\text {th }}$ edition, Pergamon Press, Oxford, UK.

Rudel, L.L., Morris, M.D. 1973. Determination of cholesterol using $O$-phthalaldehyde. Journal of Lipid Research, 14: 364.

Steel, R.G.D., Torrie, J.H., Dickey, D.A. 1997. Principles and Procedures of Statistics. A biometrical approach, $3^{\text {rd }}$ edition, Mc-Graw Hill Book Co. New York, USA.

Talpur, F.N., Memon, N.N., Bhangar, M.I. 2007. Comparison of fatty acid and cholesterol content of Pakisani buffalo breeds. Pakistan Journal of Analytical Environment Chemistry, 8: 15-20. 